\title{
Integrated pest management options for the fall armyworm Spodoptera frugiperda in West Africa: Challenges and opportunities. A review
}

\author{
Besmer Régis Ahissou ${ }^{(1,2)}$, Wendnéyidé Mathieu Sawadogo ${ }^{(1,2)}$, Aimé H. Bokonon- \\ Ganta $^{(3)}$, Irénée Somda ${ }^{(2)}$, François Verheggen ${ }^{(1)}$ \\ (1) University of Liège - Gembloux Agro-Bio Tech. TERRA. Avenue de la Faculté, 2B. BE-5030 Gembloux (Belgium). \\ E-mail: fverheggen@uliege.be \\ (2) Université Nazi Boni. Institut du Développement Rural. 01 BP 1091. Bobo-Dioulasso 01 (Burkina Faso). \\ (3) Université d'Abomey-Calavi. Faculté des Sciences Agronomiques. Laboratoire d’Entomologie Agricole. 01 BP 526 \\ Abomey-Calavi (Benin).
}

Received 21 January 2021, accepted 2 September 2021, available online 21 September 2021.

This article is distributed under the terms and conditions of the CC-BY License (http://creativecommons.org/licenses/by/4.0)

Introduction. The fall armyworm Spodoptera frugiperda (Smith) (Lepidoptera: Noctuidae) is a voracious and generalist insect pest native to America. It was first detected in West Africa in 2016 and rapidly spread across the continent. The indiscriminate use of chemical insecticides poses risks to human health and threatens the few natural enemies present in these environments. Despite the existence of alternative control measures in America (e.g. genetically modified maize), efforts are needed to develop environmentally friendly approaches that are affordable for smallholder farmers and compatible with the African context.

Literature. In this literature review, we describe the potential of the available alternative controls methods which include cultural, physical, biological and semiochemical strategies. The potential of their association is discussed considering their cost-benefice balance and local economic and agricultural context.

Conclusions. Several affordable mitigation options could be implemented rapidly, pending proper communication efforts, including (i) the promotion of indigenous natural enemies by promoting refuges and training smallholder farmers on their identification; (ii) cultural methods, mainly by planting directly after the main rainfalls, as well as performing intercropping and crop rotation; and (iii) the use of microbial biopesticides, and avoiding some of the already identified ineffective chemical insecticides.

Keywords. Biological control, fall armyworm, integrated pest management, natural enemies, smallholders, West Africa.

Options de gestion intégrée de la chenille légionnaire d'automne Spodoptera frugiperda en Afrique de l'Ouest : défis et opportunités (synthèse bibliographique)

Introduction. La chenille légionnaire d'automne Spodoptera frugiperda (Smith) (Lepidoptera : Noctuidae) est un insecte vorace et généraliste originaire d'Amérique. Il a été détecté pour la première fois en Afrique de l'Ouest en 2016 et s'est rapidement répandu sur tout le continent. L'utilisation indiscriminée d'insecticides chimiques présente des risques pour la santé humaine et menace les rares ennemis naturels présents dans ces environnements. Malgré l'existence de mesures de lutte alternatives en Amérique (par exemple, le maïs génétiquement modifié), des efforts sont nécessaires pour développer des approches respectueuses de l'environnement, abordables pour les petits exploitants et compatibles avec le contexte africain.

Littérature. Dans cette revue de la littérature, nous décrivons le potentiel des méthodes de contrôle alternatives disponibles qui incluent des méthodes culturales, physiques, biologiques et semi-chimiques. Le potentiel de leur association est discuté en tenant compte de leur équilibre coût-bénéfice et du contexte économique et agricole local.

Conclusions. Plusieurs options d'atténuation abordables pourraient être mises en œuvre rapidement, en attendant des efforts de communication appropriés, notamment (i) la promotion des ennemis naturels indigènes en favorisant les refuges et en formant les petits exploitants à leur identification; (ii) les méthodes culturales, principalement en plantant directement après les premières pluies, ainsi qu'en pratiquant l'association culturale et la rotation des cultures ; (iii) l'utilisation de biopesticides microbiens, et en évitant certains des insecticides chimiques inefficaces déjà identifiés.

Mots-clés. Lutte biologique, chenille légionnaire d'automne, lutte intégrée, ennemis naturels, petits exploitants, Afrique de l'Ouest. 


\section{INTRODUCTION}

Agriculture plays an important role in the creation of economic wealth and employment in West Africa. The food economy accounts for $66 \%$ of total employment, most of these jobs are in agriculture (78\%), specially in cereals production (FAO, 2018). Maize (Zea mays L.) is the most widely grown crop and consumed by people with varying food preferences and socio-economic background. Maize is a staple for over 200 million people who depend on that crop for food security (Day et al., 2017). But in Western Africa, maize production is hampered by several insect pests including stem borers, termites, silkworms, grasshoppers and weevils. Stem borers were previously reported as the cause of low to moderate maize yield loss (Nafiu et al., 2014; Abang et al., 2020). These include Busseola fusca Fuller, Sesamia calamistis Hampson, Chilo partellus Swinhoe and Eldana saccharina Walker (Nafiu et al., 2014). However, the recent invasion of the fall armyworm Spodoptera frugiperda (Smith), in 2016, has become the most important threat to maize production in Western Africa (Goergen et al., 2016).

The fall armyworm originates from America, where it is considered one of the most damaging agricultural pests, feeding on over 100 different crops including maize, rice, sorghum, sugarcane, tomato, potato, cotton and others (Montezano et al., 2018). It is commonly controlled by association of the latest generation of chemical insecticides with the culture of genetically modified maize (Day et al., 2017; Hruska, 2019; Matova et al., 2020). These technologies are reserved for commercial farmers who have access to subsidies and international markets seeking maize for animal feed, ethanol production and as a source of sweeteners. But maize production in West Africa is dominated by smallholder farms, whose context is very different from that of larger American farm companies. Moreover, the favorable climatic conditions in most African countries allow the pest to complete several generations per year, wherever host plants are available or not, including offseason and irrigated crops (Prasanna et al., 2018). As a result, yield losses in maize crops range from 22-67\% in Ghana, 25-50\% in Zambia, and 32-47\% in Ethiopia and Kenya (Day et al., 2017; Kumela et al., 2019).

In West-Africa, maize production is typically included in polyculture plots and the vast majority of cultivation areas are smaller than 2 ha (Day et al., 2017; Prasanna et al., 2018). Smallholder maize farmers also lack access to high and stable prices for their maize, subsidies or risk transfer mechanisms, preventing them to have access to expensive control technologies (Hruska, 2019). Chemical insecticides still constitute the bulk of the phytosanitary arsenal (Popp et al., 2013). Often effective, agrochemicals have also shown many limitations in that region:
- they are too expensive for a significant portion of smallholder farmers;

- they lead to the selection of resistant populations of pests (as highlighted recently by Sawadogo et al. [2020] in Burkina Faso);

- they have adverse effects on non-target organisms (including natural enemies) (Desneux et al., 2007) and human health (Damalas \& Eleftherohorinos, 2011).

In their current composition, the fate of chemical pesticides appears limited in the long term, as do several molecules already subject to increasing environmental and toxicological restrictions (Deguine et al., 2017). Consequently, there is a need for affordable alternatives to chemical insecticides to overcome the challenges of fall armyworm sustainable control (Bateman et al., 2018).

In this literature review, we will attempt to describe and discuss the potential of alternative options for the control of fall armyworm in the West African context. The available alternatives will be listed and discussed, including cultural, biological, physical and semiochemical strategies of control. The potential of their association is discussed considering their costbenefice balance and local economical and agricultural context. We will also analyze future prospects and action levers to ensure the transition from conventional to agro-ecological crop protection.

A systematic bibliographic research was conducted in Scopus (Elsevier), Google Scholar and BASE (Bielefeld Academic Search Engine) databases. All terms were queried as follows: "fall armyworm" OR FAW OR "Spodoptera frugiperda" OR "Laphygma frugiperda" OR "Phalaena frugiperda" OR "Trigonophora frugiperda" OR "Laphygma macra" OR "Laphygma inepta" OR "Prodenia signifera" OR "Prodenia plagiata" OR "Prodenia autumnalis" OR "Noctua frugiperda" and were associated with a combination of synonyms of one of the following keywords: integrated pest management, biological control, natural enemies, parasitoids, predators, entomopathogenic fungi, entomopathogenic viruses, entomopathogenic bacteria, entomopathogenic nematodes, pesticidal plants, cultural methods, push-pull, insecticides, smallholders, farmers' strategies, West Africa. Abstracts obtained for each research question were read to select only those directly related to the topic. This process led to the identification of 126 bibliographic references.

\section{CHEMICAL CONTROL}

In West Africa, the Sahelian Pesticides Committee (CSP) authorizes pesticides for all member countries 
of the Permanent Inter-State Committee for Drought Control in the Sahel (CILSS), which includes Benin, Burkina Faso, Cape Verde, Chad, Gambia, Guinea, Guinea Bissau, Côte d'Ivoire, Mali, Mauritania, Niger, Senegal and Togo. The CSP makes decisions common to all CILSS countries on the circulation of pesticides and their use. According to the latest update of the global list of authorized pesticides published in November 2019, no molecule is specifically registered against the fall armyworm (CSP, 2019), probably as a result of the relatively early introduction of the pest in this new area. However, the use of chemical insecticides has remained the primary means of control for fall armyworm since its introduction, although their efficacy has not been proven (Harrison et al., 2019; Sisay et al., 2019a). The molecules commonly used by farmers include emamectin benzoate, imidacloprid, lindane, chlorpyriphos-ethyl, acetamiprid, cypermethrin, lambda-cyhalothrin, deltamethrin, permethrin, maltodextrin, ethyl palmitate, carbaryl and fipronil (Rwomushana et al., 2018; Kansiime et al., 2019; Chimweta et al., 2020). In Burkina Faso for instance, more than 12,0001 of synthetic insecticides were sprayed on 14,000 ha of fall armyworm infested fields, during the 2018-2019 crop season (MAAH, 2018).

Although heavy infestations of fall armyworm in Africa may have justified chemical control, their frequent applications is unsustainable because they lead to the development of insecticide resistance, increase production costs, and cause biodiversity decline as well as health risks to the growers and consumers (Damalas \& Eleftherohorinos, 2011; Day et al., 2017). Unfortunately, problems of residue are not monitored. The fall armyworm is known to have developed strong resistance to various chemical insecticides such as pyrethroids, organochlorines, organophosphates and carbamates (Diez-Rodriguez \& Omoto, 2001) that are widely used in Africa. As a result, farmers have increased frequencies and doses of insecticide applications. However, indiscriminate spraying wastes money and can have negative effects on environment and human health, particularly in cases where knowledge about the safe use of these toxic chemicals is limited (Meagher et al., 2016). Natural enemies complex is reduced and its impact on fall armyworm populations is significantly diminished (Meagher et al., 2016). Moreover, smallholder farmers in Sub-Saharan Africa, with limited resources, cannot afford expensive chemical insecticides against fall armyworm in the long term (Khan et al., 2016). They are often unwilling or unable to purchase appropriate safety equipment, representing a high risk to human health (Day et al., 2017; Rwomushana et al., 2018). In this context, pesticides are frequently applied without adequate safety precautions, and there is increasing evidence of pesticide poisoning in Africa, although to date this is not the result of fall armyworm control (Day et al., 2017). Besides, the African pesticide market is complex due to informal distribution channels for unlabeled pesticides and the limited capacity of regulatory agencies to phase out highly hazardous compounds by replacing them with effective, low-risk alternative pesticides (Popp et al., 2013).

Many synthetic insecticides registered and recommended for controlling fall armyworm in Latin America (Day et al., 2017) are available in West Africa. Their application should be based on monitoring and thresholds, and not used as a prophylactic or preventive measure (Day et al., 2017). Pesticides should be applied when the crop is infested by a pest population sufficient to lead to yield loss greater than the cost of the intervention. Farmers should apply pesticides to coincide with the presence of first instars fall armyworm (which are easier to eliminate than older ones) using the dose and concentration recommended by the manufacturer. In addition, they should avoid treating successive generations of fall armyworm using products having the same mode of action, in order to reduce resistance risks (Day et al., 2017; Rwomushana et al., 2018). However, fall armyworm brought with it resistance to multiple insecticides that was evidenced in America many years ago (Young \& McMillian, 1979). The resistance status of this new pest to most available insecticides should be evaluated on representative populations collected from the entire area.

However, predicting the presence of a pest and then estimating the severity and incidence of an infestation allows for timely mitigation of the problem with minimal and safe means to effectively and economically protect yields (Prasanna et al., 2018). In the case of the fall armyworm, effective control program implementation requires monitoring, surveillance and detection. Lures that mimic natural pheromones are efficient in monitoring the moth populations when they are associated with sticky traps (Matova et al., 2020).

\section{CULTURAL METHODS: CULTIVATION PERIODS, RESISTANT VARIETIES, AND PLANT ASSOCIATIONS}

Recommended cultural methods include timely planting following the main rainfalls, intercropping, crop rotation and landscape management by clearing major and alternate hosts around maize fields (Assefa, 2018; Kasoma et al., 2020). Unlikely to provide adequate control alone, they help in reducing the fall armyworm populations and damages.

Early planting after the first effective rains usually provides better growing conditions for maize (Harrison et al., 2019). However, planting dates have a strong 
influence on the levels of damage inflicted by fall armyworm, as there is a synchronization between the life cycles of the insect and its host plant. A valuable option could be the creation of an asynchrony between the critical growth stages of crops and pests. Heavy infestations (occurring at the end of the crop season) can be avoided by an earlier sowing and the use of early maturing varieties (Chhetri \& Acharya, 2019). The current advice to farmers is to wait for the first 30 to $50 \mathrm{~mm}$ rains that fall in two to three consecutive days before seeding. This normally provides adequate soil moisture for crop establishment and reduces the risk of crop failure (Harrison et al., 2019). This method is effective and used by large proportions of smallholder farmers in Ghana (56\%) and Zambia (70\%) (Rwomushana et al., 2018). However, early planting may be more effective where infestation occurs through the arrival of migrant moths (Abrahams et al., 2017). Although the potential of prevention and avoidance options is considerable and well-proved, they are not yet widely implemented in Western Africa (Prasanna et al., 2018), probably because of a lack of communication efforts by local authorities.

Staggered planting in the same maize field should be avoided so as not to constantly provide food sources for the fall armyworm (Rwomushana et al., 2018; Chhetri \& Acharya, 2019). This would allow them to have their preferred food (i.e. young maize plants) over a longer time period and promote the development of local populations. In addition, late-planted maize is often infested with high levels of fall armyworm that have developed on previously planted maize (FAO, 2018; Hruska, 2019). For instance, Farmer Field School farmers in Kenya have reported higher yield losses to fall armyworm on late-planted maize plots compared to adjacent crops planted earlier (FAO, 2018).

Crop rotation is a traditional method of managing pest damage in agriculture by rotating host and non-host crops in alternate years. Unfortunately, this approach may not be directly effective against fall armyworm for two reasons. Firstly, the fall armyworm is a polyphagous pest that attacks 350 crop species belonging to diverse families, including grasses, vegetable crops, and shrubs (Montezano et al., 2018) and secondly because of the migratory nature of the pest, whose population builds up quickly in poorly managed neighboring fields (Kansiime et al., 2019). However, crop rotation improves soil fertility, provides adequate plant nutrition, supports healthy plant growth and increases pest resistance (Prasanna et al., 2018; Harrison et al., 2019). In addition, diversify the farm environment through crop rotation increases natural enemy abundance (Meagher et al., 2016; Prasanna et al., 2018).

The availability of tolerant maize varieties would be valuable, especially as regard to the economic context of Western Africa: cost-effective, easy to apply, environmentally friendly, and compatible with most other control methods (Dakouo et al., 2005). Unfortunately, there is still no maize cultivar (non-Bt maize) adapted to Africa with scientifically validated resistance to fall armyworm (Prasanna et al., 2018). Genetic selection work for maize resistance to fall armyworm was recently initiated following its identification on the continent in 2016 (Goergen et al., 2016). In West Africa, the International Institute of Tropical Agriculture (IITA) rapidly initiated traditional breeding of maize for resistance to fall armyworm. Several maize lines adapted to Africa, germplasm with natural resistance to armyworms and other varieties are also being evaluated by International Maize and Wheat Improvement Center (CIMMYT) to identify new sources of resistance compatible with the African context (Prasanna et al., 2018).

Intercropping is the establishment on the same surface of several plant species and varieties simultaneously or which cross during an important part of their growth cycle. The rows of the main crop are intercropped with additional crops in rows or strips. In general, intercropping provides a protecting microclimate that increases richness and abundance of beneficial insects (Matova et al., 2020). In Ethopia for instance, Kebede et al. (2018) reported increased abundance of generalist predators as well as the predation rate of stem borer eggs and fall armyworm by associating common bean (Phaseolus vulgaris L.) with maize. In Uganda, damages caused by the fall armyworm were significantly reduced in intercropping maize with legumes, such as P. vulgaris, Glycine max (L.) Merr. and Vigna unguiculata L. Walp. (Hailu et al., 2018).

Some plants may lead to anti-appetizing or repellent action towards insect pests of other plants. This is the basis of the push-pull approach, in which different plants growing next to each other protect themselves via substances secreted by roots, leaves, flowers or fruits (Hruska, 2019). The combination of repellent and attractive stimuli modifies the behavior of insect pests and/or their natural enemies (Cook et al., 2007). The insect pests are repelled or deterred away from a cultivated plant (push) thanks to stimuli that mask host volatile signature or are repellent or deterrent. They are simultaneously attracted (pull), using highly apparent and attractive stimuli, to other areas such as traps or trap crops where they are concentrated, facilitating their elimination (Cook et al., 2007). In their system, Cook et al. (2007) used Melinis minutiflora P.Beauv., Desmodium uncinatum (Jacq.) DC. and D. intortum (Mill.) Urb. as repellent plants to protect maize from the fall armyworm. Simultaneously, the grasses Pennisetum purpureum Schumach. and Sorghum vulgare (Pers.) were used as trap plants. In addition, M. minutiflora 
and Desmodium spp. are known to attract the parasitoids, Cotesia sesamiae Cameron (Hymenoptera: Braconidae) through volatile compounds emitted from their flowers and provide a favorable environment for their proliferation (Khan et al., 2016). The push-pull approach was shown to be effective against some stem borers, but also against other lepidopteran pests of maize and other cereals (Hassanali et al., 2008). It has been adopted by thousands of farmers in East Africa: early works in this region have demonstrated that the approach may be effective against the fall armyworm as well (Midega et al., 2018).

\section{PHYSICAL CONTROL: LOCAL FALL ARMYWORM MANAGEMENT PRACTICES}

Hand-picking of egg masses and larvae has proven a popular method for fall armyworm control in Africa, and is widely used by farmers as a first line of defence (Rwomushana et al., 2018; Yigezu \& Wakgari, 2020). Although time-consuming, it can reduce the population level when performed during the early maize development.

Several locally available substances are commonly used by smallholders to attempt to control the fall armyworm, including application of salt, urine, oils, detergents and soaps (Rwomushana et al., 2018; Hruska, 2019; Yigezu \& Wakgari, 2020). Their efficacy is not properly documented in the scientific literature, and some of them should not be recommended. An inexpensive and effective management option promoted by FAO is the application of ash or sand directly to the whorls of attacked maize plants. Sand can directly kill fall armyworm larvae, via abrasiveness or absorption of wax from the cuticle, causing larval desiccation (FAO, 2017; Hruska, 2019). Sand often contains a rich ecosystem of micro-organisms such as Bacillus thuringiensis Berliner and Beauveria bassiana (Balsamo) Vuillemin which may also promote the fall armyworm control (Ramirez-Rodriguez \& SánchezPeña, 2016). It is presented as an immediate solution for smallholder farmers who cannot afford chemical insecticides. However, the high demand for labor makes it not applicable for large plots, or is likely to increase children workload (Harrison et al., 2019). Among the other physical methods of fall armyworm management are ploughing and weeding to expose pupae to their natural enemies (Abrahams et al., 2017). In addition, burning stubbles and crop residues in infested fields could destroy unhatched eggs, larvae, pupae and adults (Assefa, 2018).

Nocturnal insects are often attracted to light sources that emit large amounts of UV radiations, and light traps may be efficient in controlling these pests (Shimoda \& Honda, 2013). Recently, a study conducted in Ethiopia reached valuable fall armyworm control results by using night-time light traps (Gebreziher, 2020). Future development and use of new light sources such as light-emitting diodes is anticipated for promoting these results of capture (Shimoda \& Honda, 2013).

\section{BIOLOGICAL CONTROL: PROMOTING INDIGENOUS NATURAL ENEMIES}

Biological control is the beneficial action of predators, parasites, pathogens, and competitors in controlling pests and their damage (Nafiu et al., 2014). The fall armyworm is attacked by various natural enemies including over 150 parasitoid species (Sisay et al., 2018), nematodes (Tendeng et al., 2019; Sun et al., 2020), diverse taxa of insect predators (Harrison et al., 2019; Koffi et al., 2020), diverse spider predators (Firake \& Behere, 2020) and entomopathogens such as fungi, bacteria and viruses (Shylesha et al., 2018). Natural enemies are responsible for significant fall armyworm mortality (up to $42 \%$ ) in its native continent . Africa may be more appropriate for fall armyworm biological control than North America for two reasons. Small scale maize production systems are predominant and other crops are often closely cultivated (Day et al., 2017) and chemical insecticides were rarely used in maize crops before the arrival of the fall armyworm in Africa in 2016 (Hruska, 2019; Caniço et al., 2020; Matova et al., 2020). Both reasons probably make natural enemies more easy to protect and promote (Midingoyi et al., 2016).

Despite the limited number of available reports, several species of fall armyworm natural enemies are encountered in Africa (Table 1). Among the parasitoid species, the hymenopterans Cotesia icipe (FernandezTriana \& Fiobe), Coccygidium luteum (Brullé), Charops ater (Szépligeti), Chelonus curvimaculatus (Cameron) and the diptera Palexorista zonata (Curran) have been found parasitizing the fall armyworm in Ethiopia, Kenya and Tanzania in 2017 (Sisay et al., 2018). While C.curvimaculatus is an egg-larval parasitoid, the other species are larval parasitoids only. In Senegal, two solitary hymenoptera belonging to Braconidae (Chelonus sp.) and Ichneumonidae (Campoletis sp.), were found to parasite $12 \%$ of the fall armyworm population (Tendeng et al., 2019). In Benin and Ghana, nine hymenopterans belonging to Braconidae [C.luteum, C.icipe, Meteoridea cf. testacea (Granger), Chelonus bifoveolatus Szépligeti], Ichneumonidae [Pristomerus pallidus (Kriechbaumer), Charops sp., Metopius discolor Tosquinet], Platygastridae (Telenomus remus Nixon), Trichogrammatidae (Trichogramma sp.) and the diptera Drino quadrizonula (Thomson) (Tachinidae) were found to parasite 5-38\% of the fall armyworm 
Table 1. Natural enemies of the fall armyworm reported after introduction into new areas of Africa and Asia since 2016 - Les ennemis naturels de la chenille légionnaire d'automne signalés après son introduction dans de nouvelles régions d'Afrique et d'Asie depuis 2016.

\begin{tabular}{llll}
\hline Species of natural enemies & Type & Countries & References \\
\hline $\begin{array}{l}\text { Arenae } \\
\text { Lycosidae }\end{array}$ & & & \\
$\quad \begin{array}{l}\text { Lycosa } \text { sp. } \\
\text { Oxyopidae }\end{array}$ & $\operatorname{Pr}$ & India & 1 \\
$\quad$ Oxyopes birmanicus Thorell & & & 1 \\
Salticidae & $\operatorname{Pr}$ & India & \\
$\quad$ Marpissa sp. & & & 1 \\
Rhene flavicomans Simon & Pr & India & 1 \\
\hline
\end{tabular}

\section{Coleoptera}

Carabidae

Undetermined sp.

Pr RD Congo 2

Chrysomelidae

Undetermined sp.

$\begin{array}{lll}\text { Pr } & \text { RD Congo }\end{array}$

Cicindelidae

Cicindela spp.

Undetermined sp.

Pr India 1

Pr RD Congo 2

Coccinellidae

Coccinella transversalis Fabricius

Harmonia octomaculata Fabricius

Undetermined sp.

Undetermined sp.

$\begin{array}{lll}\text { Pr India } & 3\end{array}$

Pr India 3

Pr RD Congo 2

Curculionidae

Undetermined sp.

$\begin{array}{lll}\text { Pr } & \text { Burkina Faso } & 4\end{array}$

Staphylinidae

Paederus fuscipes Curtis

$\begin{array}{lll}\text { Pr } & \text { RD Congo }\end{array}$

\section{Dermaptera}

Forficulidae

Forficula sp.

Undetermined sp.

Undetermined sp.

Undetermined sp.

$\begin{array}{lll}\operatorname{Pr} & \text { India } & 3,6 \\ \operatorname{Pr} & \text { India } & 1 \\ \operatorname{Pr} & \text { RD Congo } & 2 \\ \operatorname{Pr} & \text { Burkina Faso } & 4\end{array}$

\section{Diptera}

Chloropidae

Anatrichus erinaceus Loew

LP

Ghana

7

Tachinidae

Drino quadrizonula Thomson Exorista sorbillans (Wiedemann)

Exorista xanthaspis (Wiedemann)

Palexorista zonata (Curran)

Undetermined sp.

Undetermined sp.

Undetermined sp.

Undetermined sp.

$\begin{array}{lll}\text { LP } & \text { Mozambique, Ghana, Benin } & 8,9 \\ \text { LP } & \text { India } & 3 \\ \text { LP } & \text { India } & 10 \\ \text { LP } & \text { Ethiopia, Kenya } & 11,12 \\ \text { LP } & \text { Ghana } & 7 \\ \text { LPP } & \text { India } & 1 \\ * & \text { Burkina Faso } & 4 \\ \text { LP } & \text { Mozambique } & 8\end{array}$


Table 1 (continued 1). Natural enemies of the fall armyworm reported after introduction into new areas of Africa and Asia since 2016 - Les ennemis naturels de la chenille légionnaire d'automne signalés après son introduction dans de nouvelles régions d'Afrique et d'Asie depuis 2016.

\begin{tabular}{|c|c|c|c|}
\hline Species of natural enemies & Type & Countries & References \\
\hline \multicolumn{4}{|l|}{ Hemiptera } \\
\hline \multicolumn{4}{|l|}{ Nabidae } \\
\hline Undetermined sp. & $\operatorname{Pr}$ & Burkina Faso & 4 \\
\hline \multicolumn{4}{|l|}{ Pentatomidae } \\
\hline $\begin{array}{l}\text { Andrallus spinidens (Fabricius) } \\
\text { Eocanthecona furcellata (Wolff) } \\
\text { Podisus maculiventris (Say) }\end{array}$ & $\begin{array}{l}\operatorname{Pr} \\
\operatorname{Pr} \\
\operatorname{Pr}\end{array}$ & $\begin{array}{l}\text { India } \\
\text { India } \\
\text { India }\end{array}$ & $\begin{array}{l}1 \\
1,13 \\
1\end{array}$ \\
\hline \multicolumn{4}{|l|}{ Reduviidae } \\
\hline $\begin{array}{l}\text { Cosmolestes sp. } \\
\text { Haematochares obscuripennis Stål } \\
\text { Peprius nodulipes (Signoret) } \\
\text { Undetermined sp. } \\
\text { Undetermined sp. }\end{array}$ & $\begin{array}{l}\operatorname{Pr} \\
\operatorname{Pr} \\
\operatorname{Pr} \\
\operatorname{Pr} \\
\operatorname{Pr}\end{array}$ & $\begin{array}{l}\text { India } \\
\text { Ghana } \\
\text { Ghana } \\
\text { RD Congo } \\
\text { Burkina Faso }\end{array}$ & $\begin{array}{l}1 \\
7 \\
7 \\
2 \\
4\end{array}$ \\
\hline
\end{tabular}

\section{Hymenoptera}

Bethylidae

Odontepyris sp.

LP India

3

Braconidae

Bracon sp.

Chelonus bifoveolatus (Szépligeti)

Chelonus curvimaculatus Cameron

Chelonus formosanus Sonan

Chelonus sp.

Coccygidium luteum (Brullé)

Coccygidium melleum (Roman)

Cotesia icipe Fernandez-Triana \& Fiobe Cotesia ruficrus (Haliday)

Glyptapanteles creatonoti (Viereck)

Meteoridea testacea (Granger)

Microplitis manilae (Ashmead)

Formicidae

Pheidole megacephala (Fabricius)

Undetermined $\mathrm{sp}$.

ELP Ghana

ELP Ghana, Benin

EP Kenya

ELP India

LP Senegal

LP Ethiopia, Kenya, Mozambique, Tanzania, Ghana, Benin

LP India

LP Cameroon, Ethiopia, Kenya, Ghana, Benin

LP India

LP India

ELP Ghana, Benin

LP India

Pr Ghana

Pr RD Congo

LP India

LP Senegal

Campoletis sp.

Charops ater Szépligeti

Charops sp.

Eriborus sp.

Ichneumon promissorius (Erichson)

Metopius cf. discolor (Tosquinet)

Metopius rufus Ashmead

Netelia sp.

Pristomerus pallidus (Kriechbaumer)

Procerochasmias nigromaculatus

(Cameron)

Undetermined sp.

Undetermined $\mathrm{sp}$.
LP Kenya, Tanzania

LP Benin, Ghana, Mozambique

LP India

PP India

LP Mozambique, Ghana

LPP India

LP India

LP Benin

PP Cameroon

PP India

LPP India
7

7,9

11,12

1

14

$7,8,9,11,12$

3

$7,9,11,12,15$

16

6

7,9

1

7

2

3,6

14

11,12

8,9

3

1

8,9

1

1

9

15

1

6 
Table 1 (continued 2). Natural enemies of the fall armyworm reported after introduction into new areas of Africa and Asia since 2016 - Les ennemis naturels de la chenille légionnaire d'automne signalés après son introduction dans de nouvelles régions d'Afrique et d'Asie depuis 2016.

\begin{tabular}{|c|c|c|c|}
\hline Species of natural enemies & Type & Countries & References \\
\hline \multicolumn{4}{|l|}{ Platygastridae } \\
\hline Telenomus remus Nixon & EP & $\begin{array}{l}\text { South Africa, Côte d'Ivoire, Niger, Benin, Kenya, } \\
\text { Tanzania, Ghana, India, China, Cameroon }\end{array}$ & $1,9,12,15,17,18,19$ \\
\hline Telenomus sp. & $\mathrm{EP}$ & India & 6 \\
\hline Undetermined sp. & $*$ & Burkina Faso & 4 \\
\hline \multicolumn{4}{|l|}{ Sphecidae } \\
\hline Undetermined sp. & $\operatorname{Pr}$ & Burkina Faso & 4 \\
\hline \multicolumn{4}{|l|}{ Trichogrammatidae } \\
\hline $\begin{array}{l}\text { Trichogramma chilonis Ishii } \\
\text { Trichogramma } \mathrm{sp} . \\
\text { Trichogrammatoidea } \mathrm{sp} .\end{array}$ & $\begin{array}{l}\mathrm{EP} \\
\mathrm{EP} \\
\mathrm{EP}\end{array}$ & $\begin{array}{l}\text { Kenya } \\
\text { Benin, India } \\
\text { Niger }\end{array}$ & $\begin{array}{l}12 \\
6,9 \\
18\end{array}$ \\
\hline \multicolumn{4}{|l|}{ Vespidae } \\
\hline $\begin{array}{l}\text { Polistes cf. olivaceus (De Geer) } \\
\text { Ropalidia brevita Das \& Gupta } \\
\text { Undetermined sp. } \\
\text { Undetermined spp. }\end{array}$ & $\begin{array}{l}\mathrm{Pr} \\
\mathrm{Pr} \\
\mathrm{Pr} \\
\mathrm{Pr}\end{array}$ & $\begin{array}{l}\text { India } \\
\text { India } \\
\text { RD Congo } \\
\text { Burkina Faso }\end{array}$ & $\begin{array}{l}1 \\
1 \\
2 \\
4\end{array}$ \\
\hline
\end{tabular}

\section{Nematoda}

Mermithidae

\begin{tabular}{llll} 
Hexamermis cf. albicans (Siebold) & LPPa & India & 1 \\
Hexamermis sp. & LPPa Senegal & 14 \\
Ovomermis sinensis Chen & LPa & China & 20 \\
\hline
\end{tabular}

EP: egg parasitoid - parasitö̈de des œufs; LP: larval parasitoid - parasitö̈de larvaire; PP: pupal parasitoid - parasitö̈de des chrysalides; ELP: egg-larval parasitoid - parasitö̈de ovo-larvaire; LPP: larval-pupal parasitoid - parasitö̈de des larves et chrysalides; Pr: predator - prédateur; LPPa: larval-pupal parasite - parasite des larves et chrysalides; LPa: larval parasite — parasite des larves ; *: parasitoid species undetermined and stage of fall armyworm attacked unspecified - espèce de parasitoïde indéterminée et stade de la chenille légionnaire d'automne attaquée non spécifié; 1: Firake \& Behere, 2020; 2: Cokola, 2019; 3: Sharanabasappa et al., 2019; 4: Kouanda, 2020; 5: Rasheed et al., 2020; 6: Shylesha et al., 2018; 7: Koffi et al., 2020; 8: Caniço et al., 2020; 9: Agboyi et al., 2020; 10: Navik et al., 2020; 11: Sisay et al., 2018; 12: Sisay et al., 2019b; 13: Keerthi et al., 2020; 14: Tendeng et al., 2019; 15: Abang et al., 2020; 16: Gupta et al., 2019; 17: Kenis et al., 2019; 18: Laminou et al., 2020; 19: Liao et al., 2019; 20: Sun et al., 2020.

in Ghana particulary (Agboyi et al., 2020). In another study, T. remus, a parasitoid of several species of Spodoptera (Wojcik et al., 1976) was observed to attack eggs of the fall armyworm in Benin, Côte d'Ivoire, Kenya, Niger and South Africa (Kenis et al., 2019). Telenomus remus is the main egg parasitoid of fall armyworm in America, where it is already used in augmentative biological control programmes. In Ghana, Koffi et al. (2020) identified seven species of parasitoids including C.icipe and C.luteum that had previously been recorded in East Africa (Sisay et al., 2018). The other species were $C$. bifoveolatus, M. testacea, Bracon sp. (Hymenoptera), Anatrichus erinaceus Loew and an undetermined Tachinidae fly. Among these parasitoids, C.bifoveolatus (29\%) and C. luteum (24\%) were the most abundant. The same conclusion was found in another study conducted in Benin and Ghana by Agboyi et al. (2020) who identified a total of 10 eggs and larvae parasitoid species.
In addition to insect parasitoids, an entomopathogenic nematode, Hexamermis sp. (Mermithidae: Nematoda), was observed in Senegal parasitizing fall armyworm, a first report for Africa (Tendeng et al., 2019). The mermithid genus Hexamermis has worldwide distribution and they have been recorded emerging from lepidopterans in various parts of the world (Poinar, 1975). Mermithidae have been reported to feed on the insect's hemolymph and then emerge to complete their development outside the host. Infective juveniles of mermithids climb onto plants during moist conditions, usually in the morning, and infect susceptible hosts, which feed on plant parts (Nickle, 1981). Moreover, juvenile nematodes would parasitize neonate that spend a short time on the ground (Tendeng et al., 2019) by active entry through their cuticle. The entomopathogenic nematodes develop inside the host, which then lead to a slowed life with a marked decrease in their feeding. Mermithids almost always 
emerge from the insect in the last larval stage, called the postparasitic larva. It is equipped with a lance-like tooth, which is used to perforate the insect cuticle from the inside (Nickle, 1972). The violence of this emergence and the hole on the body of the insect caused by the emergence of this large mermithid usually lead to the death of the insect due to the loss of body fluids (Nickle, 1972).

Three different species of fall armyworm predators have been collected in Ghana: Haematochares obscuripennis Stål, Peprius nodulipes (Signoret) (both Hemiptera: Reduviidae) and Pheidole megacephala (F.) (Hymenoptera: Formicidae) (Koffi et al., 2020). The latter being the most abundant $(46 \%$ of the observations). They attack eggs and larvae of the fall armyworm. Other important generalist predators include Forficulidae (Dermaptera), Pentatomidae (Hemiptera), Coccinellidae (Coleoptera) and Mantidae (Mantodea), which all have been observed attacking the fall armyworm in Burkina Faso (personal observations). Their conservation requires providing refuges, food supplements and favorable propagation conditions. We suggest that the authorities provide training to smallholder farmers on the recognition, potential and practices for the preservation of these natural enemies. Considering their performance as biocontrol agent against fall armyworm in other parts of the world, further studies should be conducted to assess their potential in West Africa, before designing more comprehensive IPM strategies for the management of the fall armyworm.

Among the other methods of fall armyworm management is the application of sugar water to attract predators and parasitoids. A work carried out in Honduras by Canas \& O'Neil (1998) showed a reduction of $18 \%$ of infested plants, and a reduction of $35 \%$ of damage caused by fall armyworm in maize fields where sugar water was applied. In some parts of Africa, fish soup is applied instead of sugar water, to reach the same effect (Harrison et al., 2019). However, successful and effective implementation of these measures is highly dependent on the availability of natural enemies in the field vicinity, hence the importance of agro-ecological infrastructure. Increasing vegetable and floral biodiversity in the edges of maize fields is among the most valuable options. Mexican sunflower (Tithonia diversifolia [Hemsl.] A.Gray) and Crotalaria crops planted in maize field borders increased the biodiversity of beneficial insects such as different ant species (Prasanna et al., 2018), some of them being predators of fall armyworm (Koffi et al., 2020).

In East Africa, the abundance of stem borers predators (ants, earwigs and spiders) was increased in fields intercropping maize and Desmodium, D. uncinatum, with Napier grass (P.purpureum) as trap crop around the field (push-pull) (e.g. Kebede etal., 2018). In an extension of push-pull approach, it was observed that intercropping maize with the nonhost molasses grass M.minutiflora and Desmodium spp. significantly decreased levels of infestation by certain stem borer species in the main crop and also increased the parasitism of stem borer larvae by C. sesamiae (Khan et al., 2016). Push-pull approach may not only impact some stem borer species, but also other lepidopteran pests of maize and other cereals (Hassanali et al., 2008). Similary, a work carried out in Peru by Quispe et al. (2017) showed a better attraction of fall armyworm parasitoids and predators with refuge plants such as: Foeniculum vulgare Mill., Gossypium barbadense L., Bidens pilosa L., Helianthus annuus L., Malva parviflora L., Galinsoga parviflora Cav. and Sorghum halepense (L.) Pers.

\section{BIOLOGICAL INSECTICIDES: PESTICIDAL PLANTS AND MICROBIAL BIOPESTICIDES}

Several plant species are recognized by African smallholder farmers as having pesticidal properties. Either their leaves, flowers, fruits, seeds, bark or roots produce a wide variety of secondary metabolites that are repellent or toxic to insect pests. Yarou et al. (2017) listed 20 pesticidal plants specifically used in West Africa to control arthropod pests of vegetable crops. Compared to chemical insecticides, they are expected to be more environmentally friendly due to their short persistence, lower requested concentrations of a more diverse range of active substances and anti-feeding/ repellent modes of action (Bhusal \& Chapagain, 2020). According to the molecules registered in America, a recent analysis of national lists of pesticides and biopesticides from 19 African countries identified 29 biopesticides which could be allowed for use in fall armyworm management (Bateman et al., 2018), pending their efficacy is proven against this new pest.

Following the introduction of the fall armyworm in Africa, a few studies have evaluated the efficacy of pesticidal plants for the control of this pest (Table 2). Seven plant extracts have shown potential in controling the fall armyworm (i.e. mortality greater than $75 \%$ after a 72-hour exposure): Azadirachta indica A.Juss., Phytolacca dodecandra (L'Her.), Schinus molle L., Jatropha curcas L., Melia abyssinica L., Millettia ferruginea (Hochst.) Baker and Croton macrostachyus Hochst. ex Delile (Sisay et al., 2019a). Among these pesticidal plants, neem is probably the most widely used (James et al., 2010; Yarou et al., 2017). In other contact toxicity and feeding bioassays, the highest larval mortalities were obtained with Nicotiana tabacum L. and Lippia javanica (Burm.f.) Spreng (Phambala et al., 2020). The same authors also 
Table 2. Toxicity of pesticidal plants assessed on fall armyworm in Africa since 2016 - Toxicité des plantes pesticides évaluée sur la chenille légionnaire d'automne en Afrique depuis 2016.

\begin{tabular}{|c|c|c|c|c|}
\hline Pesticidal plants & Mortality (\%) & Efficacy & Countries & References \\
\hline Aloe vera (L.) Burm.f. & 23 & Lab \& field & Malawi & 1 \\
\hline Azadirachta indica A.Juss. & $60-98$ & Lab \& field & Ethiopia, Malawi, Benin & $1,2,3$ \\
\hline Capsicum аппиит $\mathrm{L}$. & Unknown & Field & Burkina Faso & 4 \\
\hline Cassia nigricans Vahl & Unknown & Field & Burkina Faso & 4 \\
\hline Chenopodium ambrosioides L. & 21 & $\mathrm{Lab}$ & Ethiopia & 2 \\
\hline Cleome viscosa $\mathrm{L}$. & Unknown & Field & Burkina Faso & 4 \\
\hline Croton macrostachyus Hochst. ex Delile & 75 & $\mathrm{Lab}$ & Ethiopia & 2 \\
\hline Cymbopogon citratus (DC.) Stapf & 50 & Lab \& field & Malawi & 1 \\
\hline Eucalyptus globulus Labill. & 8 & $\mathrm{Lab}$ & Ethiopia & 2 \\
\hline Jatropha curcas L. & 91 & Lab & Ethiopia & 2 \\
\hline Lantana camara L. & $10-40$ & Lab \& field & Ethiopia, Malawi & 1,2 \\
\hline Lippia javanica (Burm.f.) Spreng. & 66 & Lab \& field & Malawi & 1 \\
\hline Melia abyssinica $\mathrm{L}$. & 90 & $\mathrm{Lab}$ & Ethiopia & 2 \\
\hline Millettia ferruginea (Hochst.) Baker & 78 & $\mathrm{Lab}$ & Ethiopia & 2 \\
\hline Nicotiana tabacum L. & $50-66$ & Lab \& field & Ethiopia, Malawi & 1,2 \\
\hline Ocimum basilicum $\mathrm{L}$. & 26 & Lab \& field & Malawi & 1 \\
\hline Parkia biglobosa (Jacq.) G.Don & Unknown & Field & Burkina Faso & 4 \\
\hline Phytolacca dodecandra L'Her. & 96 & Lab & Ethiopia & 2 \\
\hline Schinus molle L. & 96 & $\mathrm{Lab}$ & Ethiopia & 2 \\
\hline Tephrosia vogelii Hook.f. & $<10$ & Lab \& field & Malawi & 1 \\
\hline Trichilia emetica Vahl & 20 & Lab \& field & Malawi & 1 \\
\hline Vernonia amygdalina Delile & 38 & Lab \& field & Malawi & 1 \\
\hline
\end{tabular}

1: Phambala et al., 2020; 2: Sisay et al., 2019a; 3: Adeye et al., 2018; 4: Kambou \& Millogo, 2019.

suggested that Cymbopogon citratus (DC.) Stapf. and A. indica had some valuable deterrent effects (36 and $20 \%$, respectively). In Burkina Faso, the use of aqueous extracts of Cassia nigricans Vahl also resulted in a $13 \%$ reduction of fall armyworm infestation in maize (Kambou \& Millogo, 2019). These insecticides, as well as others also based on neem, capsaicin, orange oil and other aromatic plants, are commercially available in several African countries (Bateman et al., 2018).

Microbial biopesticides include bacteria, fungi, viruses and protozoa used for the biological control of pestiferous insects, plant pathogens and weeds (Chandler et al., 2011; Deravel et al., 2014). Fungi (Metarhizium rileyi [Farl.], M. anisopilae [Metschnikoff] Sorokin, B.bassiana), bacteria (B.thuringiensis) and protozoans have been suggested as the best option for the biological control of the fall armyworm (Chhetri \& Acharya, 2019). Entomopathogenic fungi are already widespread in maize fields and naturally contribute to the suppression of many crop pests (Vega, 2018). After the introduction of the fall armyworm, larvae infected with entomopathogenic fungi were found in African maize fields according to early reports (Chinwada, 2018; Cokola, 2019). Beauveria bassiana is one of the most commonly used as biological control agent worldwide (James et al., 2010), and has been identified in maize fields in West Africa (Cherry et al., 1999; Cherry et al., 2004). Recently, B. bassiana was demonstrated efficient against eggs and second instar larvae of fall armyworm (Akutse et al., 2019). Some commercially available products, based on M.anisopliae or B. bassiana are available on the west African market (Bateman et al., 2018; CSP, 2019).

Several entomopathogenic bacteria also infect insects by ingestion and sometimes via parasitoids and predators. Those belonging to the families of Bacillaceae, Enterobacteriaceae and Pseudomonadaceae were the most widespread among the microbiome of 30 lepidopteran species (Paniagua Voirol et al., 2018). Among them, B.thuringiensis are gram-positive bacteria producing toxic crystalline 
proteins called delta-endotoxins or Cry protoxins, which cause rapid deathafter ingestion (Popp et al., 2013). In several West African countries, a number of microbial biopesticides based on these bacteria are registered and commercialy available: $B$. thuringiensis var. Kurstaki and B.thuringiensis subsp. Aizawai (Bateman et al., 2018; CSP, 2019). However, the efficacy of these microbial biopesticides against the fall armyworm and their natural enemies remains to be properly evaluated (Kasoma et al., 2020). In Central America, some smallholder farmers have developed their own artisanal production of entomopathogens, that they apply in maize fields. Others collect the dead larvae from their fields, crush them and apply a solution of the extract into maize plants infested with fall armyworm (Hruska, 2019). Both approaches led to significant results.

Recently, some entomopathogens were recovered from dead fall armyworm larvae and pupae in Madagascar, India and Indonesia. These biocontrol agents belonging to entomopathogenic fungi (M.anisopliae, Nomuraea (=Metarhizium) rileyi, B.bassiana), entomopathogenic virus (Spodoptera frugiperda Nuclear Polyhydrosis Virus (SpfrNPV), Spodoptera frugiperda multiple nucleopolyhedro virus (SfMNPV) and entomopathogenic bacteria (Bacillus sp.) (Chinwada, 2018; Shylesha et al., 2018; Sharanabasappa et al., 2019; Firake \& Behere, 2020).

\section{ADDITIONAL RECOMMENDATIONS AND PERSPECTIVES}

Presently, alternative practices to chemical insecticides play a marginal role in the control of insect pests in production systems in West Africa. The pesticide market is still dominated by chemical pesticides despite the development of biopesticides and genetically modified plants (Thakore, 2006). With the exception of neem, plant biopesticides are not yet commercialized on a large scale due to the lack of control over their stability by ordinary manufacturers. Lack of material, financial resources and appropriate equipment also limit the production and availability of these plant biopesticides (Yarou et al., 2017). However, the biopesticide market is growing faster than that of chemical pesticides (Popp et al., 2013). Many biological control agents are not considered acceptable by farmers because they are evaluated for their immediate impact on insect pests. Compared to chemical pesticides, disadvantages of biopesticides include a slower rate of insect elimination, shorter persistence in the environment and sensitivity to adverse environmental conditions (Chandler et al., 2011; Popp et al., 2013; Rioba \& Stevenson, 2020). However, agro-ecological management of insect pests not only has positive economic benefits, but it is crucial for biodiversity conservation (Epstein et al., 2021). For this reason, evaluation of the efficacy of biological control agents must consider long-term impacts rather than only short-term performance, as is generally the case with conventional practices. However, the future of biopesticides in West Africa may depend on market forces rather than on their ability to compete with chemical pesticides as environmentally friendly alternatives, as in Kenya (Coulibaly et al., 2007).

Reports are accumulating from over the planet to show the status of resistance of the fall armyworm to most of the active substances, and associated modes of action (Diez-Rodriguez \& Omoto, 2001; GutiérrezMoreno et al., 2019). Since West Africa is lacking data on the resistance status of the fall armyworm to the available insecticide substances, we suggest the establishment of laboratories accredited to measure susceptibility and resistance to the major classes of pesticides in all areas where the fall armyworm is present. A similar suggestion has recently been made for another invasive pest, Tuta absoluta Meyrick (Sawadogo et al., 2020). A unique methodology should be followed and applied to populations collected from the main maize areas of West African. The identification of less effective substances would allow to build a communication strategy at each country level.

Farmers need training to improve their knowledge, self-confidence, skill levels, and willingness to make no-spray decisions when it is safe to skip an insecticide application (Prasanna et al., 2018). In addition, farmers involved in the agro-ecological transition stated that it can only be done with collectivity support, adapted accompaniment and training or coaching (Claveirole, 2016). Continuous training of farmers is imperative in order to equip them and give them more autonomy. Evaluation of farmer awareness of the range of entomofauna associated with sorghum and groundnut in Burkina Faso show that farmers have a fairly detailed knowledge of most of the major arthropod pests. Conversely, while they are able to identify some predatory arthropods, they do not know their usefulness in controlling crop pests (Dicko et al., 1998). One of the best ways to meet this need is using of Farmers Field Schools, combined with various means of awareness and communication (Prudent et al., 2006). For example, the dissemination of push-pull in East Africa has been done through several means of communication, including videos, radio scripts, brochures and training materials for producers in several languages. Push-pull system is one of the most successful examples of conservation biological control (Prasanna et al., 2018). Farmer Field Schools improve farmers' knowledge and adoption of beneficial practices, and reduce overuse of pesticides. However, the success of these training initiatives also implies permanent interactions between scientists, 
farmers and those who define and implement public policies. Many farmers innovate and create in order to improve their products and reduce their production costs (Claveirole, 2016). Their knowledge must also be considered during exchanges of practices and knowhow, observations and experiments. In the transition towards agro-ecological crop protection, appropriation of knowledge is based not only on the knowledge flows generated by the combination of disciplines, but also on discussions, practice and sharing of experiences (field meetings, group workshops) within a target or mixed audience maintaining the progress loop that drives agro-ecological evolution (Deguine et al., 2017).

Alternatives should also be developed considering the specific context of West African countries. Agroecological practices and techniques have exceptional potential for the management of insect pests in crops while simultaneously helping the transition from conventional agriculture to agro-ecology. As an alternative, agro-ecological crop protection helps to overcome many problems resulting in chemical control such as: development of insecticide resistance, increases production costs, and negative environmental and human health impacts (Damalas \& Eleftherohorinos, 2011; Akutse et al., 2019). Resistance to biological control agents has not been observed in the fall armyworm; the cost of biological control, particularly classical and conservation biological control, is much lower and benefits smallholder production systems in Africa (Prasanna et al., 2018). Natural resources and habitat management are important for agro-ecological crop protection using biological control agents, resistant or tolerant cultivars, plant biopesticides, while reducing pesticide use by more than $90 \%$ in integrated farms (Reddy, 2017; Rioba \& Stevenson, 2020). Generally, agro-ecological crop protection offers sustainable with negligible ecological impacts, is cost-effective and harmless to beneficial organisms and other non-target species compared to chemical pesticides (Reddy, 2017). It also boosts employment opportunities through the development of small local industries (Rioba \& Stevenson, 2020) for the production of quality bioproducts based on fungi, bacteria, viruses, and nematodes. For instance, local production of Trichograms for the control of fall armyworm and other lepidopteran species harmful to crops has been successful in a number of countries such as Brazil and Egypt (Hruska, 2019).

\section{CONCLUSIONS}

In West Africa, maize protection against the fall armyworm becomes essential. Cultural practices (early planting, intercropping, crop rotation, trap crops) should be promoted with more consideration, due to their easy implementation. Curative control of fall armyworm should give priority to biopesticides such as microbial pesticides. In order to exploit this potential, it is important to evaluate the diversity and effectiveness of natural enemies on the continent. The chemical pesticides that have to be applied when the damage exceeds economic threshold should have lower toxicity to natural enemies and human health. Furthermore, some local practices and innovations used by smallholder farmers should be evaluated in order to scientifically establish their effectiveness and robustness in space and time. Participative approach, Farmers Field Schools, adapted accompaniment and training of smallholder farmers would increase the competitiveness and adoption of alternative methods to chemical pesticides.

\section{Acknowledgements}

This research was funded by the Academy of Research and Higher Education-Commission Development Cooperation (ARES-CDD) as part of the PRD AGRO-ECO project.

\section{Bibliography}

Abang A.F. et al., 2020. Spatio-temporal partitioning and sharing of parasitoids by fall armyworm and maize stemborers in Cameroon. J. Appl. Entomol., 145, 55-64, doi.org/10.1111/jen.12827

Abrahams P. et al., 2017. Fall armyworm status - Impacts and control options in Africa: preliminary evidence note (April 2017). Wallingford, UK: CABI.

Adeye A.T. et al., 2018. Protection de la culture de maïs contre Spodoptera frugiperda avec les insecticides Plantneem, Lambdace 25 EC et Viper 46 EC et réduction de pertes de rendement au Bénin. J. Rech. Sci. Univ. Lomé, 20(2), 53-65.

Agboyi L.K. et al., 2020. Parasitoid complex of fall armyworm, Spodoptera frugiperda, in Ghana and Benin. Insects, 11(2), 68, doi.org/10.3390/insects 11020068

Akutse K.S.etal.,2019.Ovicidaleffects of entomopathogenic fungal isolates on the invasive fall armyworm Spodoptera frugiperda (Lepidoptera: Noctuidae). J. Appl. Entomol., 143, 626-634, doi.org/10.1111/jen.12634

Assefa F., 2018. Status of fall armyworm (Spodoptera frugiperda), biology and control measures on maize crop in Ethiopia: a review. Int. J. Entomol. Res., 06(02), 7585, doi.org/10.33687/entomol.006.02.2498

Bateman M.L. et al., 2018. Assessment of potential biopesticide options for managing fall armyworm (Spodoptera frugiperda) in Africa. J. Appl. Entomol., 142, 805-819, doi.org/10.1111/jen.12565

Bhusal S. \& Chapagain E., 2020. Threats of fall armyworm (Spodoptera frugiperda) incidence in Nepal and its integrated management-a review. J. Agric. Nat. Resour., 3(1), 345-359, doi.org/10.3126/janr.v3i1.27186 
Canas L.A. \& O’Neil R.J., 1998. Applications of sugar solutions to maize, and the impact of natural enemies on fall armyworm. Int. J. Pest Manage., 44(2), 59-64, doi. org/10.1080/096708798228329

Caniço A., Mexia A. \& Santos L., 2020. First report of native parasitoids of fall armyworm Spodoptera frugiperda Smith (Lepidoptera: Noctuidae) in Mozambique. Insects, 11(615), 1-12, doi.org/10.3390/insects 11090615

Chandler D. et al., 2011. The development, regulation and use of biopesticides for integrated pest management. Philos. Trans. R. Soc. B, 366, 1987-1998, doi. org/10.1098/rstb.2010.0390

Cherry A.J., Lomer C.J., Djegui D. \& Schulthess F., 1999. Pathogen incidence and their potential as microbial control agents in IPM of maize stem borers in West Africa. BioControl, 44, 301-327, doi. org/10.1023/A:1009991724251

Cherry A.J., Banito A., Djegui D. \& Lomer C., 2004. Suppression of the stem-borer Sesamia calamistis (Lepidoptera; Noctuidae) in maize following seed dressing, topical application and stem injection with African isolates of Beauveria bassiana. Int. J. Pest Manage., 50(1), 67-73, doi.org/10.1080/096708703100 01637426

Chhetri L.B. \& Acharya B., 2019. Fall armyworm (Spodoptera frugiperda): a threat to food security for south Asian country: control and management options : a review. Farming Manage., 4(1), 38-44, doi. org/10.31830/2456-8724.2019.004

Chimweta M., Nyakudya I.W., Jimu L. \& Mashingaidze A.B., 2020. Fall armyworm [Spodoptera frugiperda (J.E. Smith)] damage in maize: management options for flood- recession cropping smallholder farmers. Int. J. Pest Manage., 66(2), 142-154, doi.org/10 $.1080 / 09670874.2019 .1577514$

Chinwada P., 2018. Évaluation de la prévalence de la chenille légionnaire d'automne à Madagascar-Rapport de mission. Rome : FAO.

Claveirole C., 2016. La transition agroécologique : défis et enjeux. Les avis du CESE. Paris: Les éditions des Journaux officiels.

Cokola M.C., 2019. Monitoring, caractérisation moléculaire et lutte biologique contre Spodoptera frugiperda (Lepidoptera: Noctuidae). Travail de fin d'étude : Université de Liège - Gembloux Agro-Bio Tech, Gembloux (Belgique).

Cook S.M., Khan Z.R. \& Pickett J.A., 2007. The use of push-pull strategies in integrated pest management. Annu. Rev. Entomol., 52, 375-400, doi.org/10.1146/ annurev.ento.52.110405.091407

Coulibaly O. et al., 2007. Vegetable producer perceptions and willingness to pay for biopesticides. J. Veg. Sci., 12(3), 27-42, doi.org/10.1300/J484v12n03_04

CSP, 2019. Liste des pesticides autorisés par la 45 ème session ordinaire du Comité Sahélien des Pesticides. Ouagadougou : Comité Permanent Inter-Etats de Lutte contre la Sècheresse dans le Sahel (CILSS), Comité Sahélien des Pesticides (CSP), http://www.insah.org/ doc/pdf/liste_pesticides_autotises_par_45eSession_ CSP_Nov-2019.pdf, (02/07/2020)

Dakouo D. et al., 2005. Lutte génétique contre la cécidomyie du sorgho, Stenodiplosis sorghicola: une contrainte majeure à la production du sorgho au Burkina Faso. Cah . Agric., 14(2), 201-208.

Damalas C.A. \& Eleftherohorinos I.G., 2011. Pesticide exposure, safety issues, and risk assessment indicators. Int . J. Environ. Res. Public Health, 8(5), 1402-1419, doi. org/10.3390/ijerph8051402

Day R.K. et al., 2017. Fall armyworm: impacts and implications for Africa. Outlooks Pest Manage., 28(5), 196-201, doi.org/10.1564/v28_oct_02

Deguine J.-P. et al., eds., 2017. Agroecological crop protection. Versailles, France : Éditions Quæ, doi. org/10.1007/978-94-024-1185-0

Deravel J., Krier F. \& Jacques P., 2014. Les biopesticides, compléments et alternatives aux produits phytosanitaires chimiques (synthèse bibliographique). Biotechnol. Agron. Soc. Environ., 18(2), 220-232.

Desneux N., Decourtye A. \& Delpuech J.-M., 2007. The sublethal effects of pesticides on beneficial arthropods. Annu. Rev. Entomol., 52, 81-106, doi.org/10.1146/ annurev.ento.52.110405.091440

Dicko I.O. et al., 1998. Évaluation des connaissances paysannes sur la diversité de l'entomofaune du sorgho et de l'arachide au Burkina Faso. Agric. Dév., 20, 25-32.

Diez-Rodriguez G.I. \& Omoto C., 2001. Herança da Resistência de Spodoptera frugiperda (J.E. Smith) (Lepidoptera: Noctuidae) a Lambda-Cialotrina. Neotrop. Entomol., 30(2), 311-316, doi.org/10.1590/S1519566 X2001000200016

Epstein Y., Chapron G. \& Verheggen F., 2021. EU court to rule on banned pesticide use. Science, 373(6552), 290, doi.org/10.1126/science.abj9226

FAO, 2017. Gestion durable de la chenille légionnaire d'automne en Afrique - Programme d'action de la FAO. Rome : FAO.

FAO, 2018. Integrated management of the fall armyworm on maize: a guide for farmer field schools in Africa. Roma : FAO.

Firake D.M. \& Behere G.T., 2020. Natural mortality of invasive fall armyworm, Spodoptera frugiperda (J. E. Smith) (Lepidoptera: Noctuidae) in maize agroecosystems of northeast India. Biol. Control, 148, 1-11, doi.org/10.1016/j.biocontrol.2020.104303

Gebreziher H.G., 2020. Review on management methods of fall armyworm (Spodoptera frugiperda JE Smith) in Sub-Saharan Africa. Int. J. Entomol. Res., 5(2), 9-14.

Goergen G. et al., 2016. First report of outbreaks of the fall armyworm Spodoptera frugiperda (J E Smith) (Lepidoptera, Noctuidae), a new alien invasive pest in West and Central Africa. PLoS One, 11(10), e0165632, doi.org/10.1371/journal.pone.0165632 
Gupta A., Babu S.R. \& Kumar M.S., 2019. Cotesia ruficrus (Haliday, 1834) (Hymenoptera: (J. E. Smith) (Lepidoptera: Noctuidae) in Indian maize fields. J. Biol. Control, 33(3), 193-196, doi.org/10.18311/ jbc/2019/24118

Gutiérrez-Moreno R. et al., 2019. Field-evolved resistance of the fall armyworm (Lepidoptera: Noctuidae) to synthetic insecticides in Puerto Rico and Mexico. J. Econ. Entomol., 112(2), 792-802, doi.org/10.1093/jee/ toy 372

Hailu G. et al., 2018. Maize-legume intercropping and pushpull for management of fall armyworm, stemborers, and striga in Uganda. Agron. J., 110(6), 2513-2522, doi. org/10.2134/agronj2018.02.0110

Harrison R.D. et al., 2019. Agro-ecological options for fall armyworm (Spodoptera frugiperda JE Smith) management: providing low-cost, smallholder friendly solutions to an invasive pest. J. Environ. Manage., 243, 318-330, doi.org/10.1016/j.jenvman.2019.05.011

Hassanali A. et al., 2008. Integrated pest management: the push-pull approach for controlling insect pests and weeds of cereals, and its potential for other agricultural systems including animal husbandry. Philos. Trans. R. Soc. B, 363, 611-621, doi.org/10.1098/rstb.2007.2173

Hruska A.J., 2019. Fall armyworm (Spodoptera frugiperda) management by smallholders. CAB Rev., 14(043), 1-11, doi.org/10.1079/PAVSNNR201914043

James B. et al., 2010. Gestion intégrée des nuisibles en production maraîchère: guide pour les agents de vulgarisation en Afrique de l'Ouest. Ibadan: Institut International d'Agriculture Tropicale (IITA).

Kambou G. \& Millogo A.M., 2019. Biological efficiency of natural substances aqueous extracts (Cassia nigricans Vahl., Parkia biglobosa (Jacq.) R. Br. Ex G. Donf., Capsicum annum L., Cleome viscosa L.) against Spodoptera frugiperda J.E. Smith on corn production and their effects on a fer. J. Environ. Sci. Comput. Sci. Eng. Technol.,8(1),36-51,doi.org/10.24214/jecet.A.8.1.03651

Kansiime M.K. et al., 2019. Farmer perception of fall armyworm (Spodoptera frugiderda J.E. Smith) and farmlevel management practices in Zambia. Pest Manage. Sci., 75, 2840-2850, doi.org/10.1002/ps.5504

Kasoma C., Shimelis H.\& Laing M.D., 2020. Fall armyworm invasion in Africa: implications for maize production and breeding. J. Crop Improv., 35(1), 111-146, doi.org/10.10 80/15427528.2020.1802800

Kebede Y., Baudron F., Bianchi F. \& Tittonell P., 2018. Unpacking the push-pull system: assessing the contribution of companion crops along a gradient of landscape complexity. Agric. Ecosyst. Environ., 268, 115-123, doi.org/10.1016/j.agee.2018.09.012

Keerthi M.C. et al., 2020. Performance of the native predatory bug, Eocanthecona furcellata (Wolff) (Hemiptera: Pentatomidae), on the fall armyworm, Spodoptera frugiperda (J. E. Smith) (Lepidoptera: Noctuidae), and its limitation under field condition. Egypt. J. Biol. Pest
Control, 30(69), 1-4, doi.org/10.1186/s41938-02000272-7

Kenis M. et al., 2019. Telenomus remus, a candidate parasitoid for the biological control of Spodoptera frugiperda in Africa, is already present on the continent. Insects, 10(92), 1-10, doi.org/10.3390/insects10040092

Khan Z.R., Midega C.A.O., Hooper A.M. \& Pickett J.A., 2016. Push-pull: chemical ecology-based integrated pest management technology. J. Chem. Ecol., 42, 689-697, doi.org/10.1007/s 10886-016-0730-y

Koffi D. et al., 2020. Natural enemies of the fall armyworm, Spodoptera frugiperda (J.E. Smith) (Lepidoptera: Noctuidae) in Ghana. Florida Entomol., 103(1), 85-90, doi.org/10.1653/024.103.0414

Kouanda N., 2020. Monitoring et méthodes alternatives de lutte contre Spodoptera frugiperda J.E Smith dans la région du Centre-Ouest du Burkina Faso. Travail de fin d'étude : Université de Liège - Gembloux Agro-Bio Tech, Gembloux (Belgique).

Kumela T. et al., 2019. Farmers' knowledge, perceptions, and management practices of the new invasive pest, fall armyworm (Spodoptera frugiperda) in Ethiopia and Kenya. Int. J. Pest Manage., 65(1), 1-9, doi.org/10.1080/ 09670874.2017.1423129

Laminou S. et al., 2020. Parasitism of locally recruited egg parasitoids of the fall armyworm in Africa. Insects, 11(430), 1-13, doi.org/10.3390/insects 11070430

Liao Y.-L. et al., 2019. First report of Telenomus remus parasitizing Spodoptera frugiperda and its field parasitism in southern China. J. Hymen. Res., 102, 95-102, doi. org/10.3897/jhr.73.39136

MAAH (Ministère de l'Agriculture et des Aménagements Hydrauliques), 2018. Lutte contre la chenille légionnaire d'automne au Burkina Faso (Campagne agricole 20182019). Rapport général. Ouagadougou : MAAH.

Matova P.M. et al., 2020. Fall-armyworm invasion, control practices and resistance breeding in Sub-Saharan Africa. Crop Sci., 60, 2951-2970, doi.org/10.1002/csc2.20317

Meagher R.L.,Nuessly G.S.,Nagoshi R.N.\&Hay-Roe M.M., 2016. Parasitoids attacking fall armyworm (Lepidoptera: Noctuidae) in sweet corn habitats. Biol. Control, 95, 6672, doi.org/10.1016/j.biocontrol.2016.01.006

Midega C.A.O. et al., 2018. A climate-adapted push-pull system effectively controls fall armyworm, Spodoptera frugiperda (J E Smith), in maize in East Africa. Crop Prot., 105, 10-15, doi.org/10.1016/j.cropro.2017.11.003

Midingoyi S.G. et al., 2016. Assessing the long-term welfare effects of the biological control of cereal stemborer pests in East and Southern Africa: evidence from Kenya, Mozambique and Zambia. Agric. Ecosyst. Environ., 230, 10-23, doi.org/10.1016/j.agee.2016.05.026

Montezano D.G. et al., 2018. Host plants of Spodoptera frugiperda (Lepidoptera: Noctuidae) in the Americas. Afr. Entomol., 26(2), 286-300, doi.org/10.4001/003.026.0286

Nafiu B.S., Dong H. \& Mustapha S., 2014. Biological control of insect pests in West Africa: a review. Int. 
J. Appl. Res. Technol., 3(9), 39-45, doi.org/10.13140/ RG.2.2.13034.31687

Navik O., Venkatesan T. \& Ashika T.R., 2020. First report of Exorista xanthaspis (Wiedemann, 1830) (Diptera: Tachinidae), a larval-pupal parasitoid on invasive pest, Spodoptera frugiperda (J. E. Smith) in maize from India. J. Biol. Control, 34(1), 82-85, doi.org/10.18311/ jbc/2020/24933

Nickle W.R., 1972. A contribution to our knowledge of the Mermithidae (Nematoda). J. Nematol., 4(2), 113-146.

Nickle W.R., 1981. Mermithid parasites of agricultural pest insects. J. Nematol., 13(3), 262-266.

Paniagua Voirol L.R. et al., 2018. Bacterial symbionts in Lepidoptera: their diversity, transmission, and impact on the host. Front. Microbiol., 9(556), 1-14, doi. org/10.3389/fmicb.2018.00556

Phambala K. et al., 2020. Bioactivity of common pesticidal plants on fall armyworm larvae (Spodoptera frugiperda). Plants, 9(112), 1-10, doi.org/10.3390/plants9010112

Poinar G.O., 1975. Entomogenous nematodes. A manual and host list of insect-nematode associations. Leiden, The Netherlands: E.J. Brill.

Popp J., Pető K. \& Nagy J., 2013. Pesticide productivity and food security. A review. Agron. Sustain.Dev., 33(1), 243-255, doi.org/10.1007/s 13593-012-0105-x

Prasanna B.M., Huesing J.E., Eddy R. \& Peschke V.M., eds, 2018. Fall armyworm in Africa: a guide for integrated pest management. $1^{\text {st }}$ ed. Mexico, CDMX: CIMMYT.

Prudent P., Loko S. \& Vaissayre M., 2006. Les écoles paysannes au Bénin : une approche participative de la diffusion des messages relatifs à la protection intégrée du cotonnier. Cah. Agric., 15(1), 100-101.

Quispe R., Mazón M. \& Rodríguez-Berrío A., 2017. Do refuge plants favour natural pest control in maize crops? Insects, 8(3), 71, doi.org/10.3390/insects 8030071

Ramirez-Rodriguez D. ～\& Sánchez-Peña S.R., 2016. Endophytic Beauveria bassiana in Zea mays: pathogenicity against larvae of fall armyworm, Spodoptera frugiperda. Southwest. Entomol., 41(3), 875-878, doi.org/10.3958/059.041.0330

Rasheed V.A. et al., 2020. Occurrence of fall armyworm, Spodoptera frugiperda (J. E. Smith) (Lepidoptera: Noctuidae), in Chittoor district of Andhra Pradesh, India with a note on rove beetle as its potential natural enemy. J. Biol. Control, 34(1), 86-89, doi.org/10.18311/ $\mathrm{jbc} / 2020 / 25316$

Reddy P.P., 2017. Agro-ecological approaches to pest management for sustainable agriculture. Singapore: Springer Nature.

Rioba N.B. \& Stevenson P.C., 2020. Opportunities and scope for botanical extracts and products for the management of fall armyworm (Spodoptera frugiperda) for smallholders in Africa. Plants, 9(2), 1-17, doi. org/10.3390/plants9020207

Rwomushana I. et al., 2018. Fall armyworm: impacts and implications for Africa. Wallingford, UK: CABI.
Sawadogo W.M. et al., 2020. Insecticide susceptibility level and control failure likelihood estimation of Sub-Saharan African populations of tomato leafminer: evidence from Burkina Faso. Physiol. Entomol., 45(4), 147-153, doi.org/10.1111/phen.12332

Sharanabasappa et al., 2019. Natural enemies of Spodoptera frugiperda (J. E. Smith) (Lepidoptera: Noctuidae), a recent invasive pest on maize in South India. Florida Entomol., 102(2), 619-623.

Shimoda M. \& Honda K., 2013. Insect reactions to light and its applications to pest management. Appl. Entomol. Zool., 48, 413-421, doi.org/10.1007/s13355013-0219-x

Shylesha A.N. et al., 2018. Studies on new invasive pest Spodoptera frugiperda (J. E. Smith) (Lepidoptera: Noctuidae) and its natural enemies. J. Biol. Control, 32(3), doi.org/10.18311/jbc/2018/21707

Sisay B. et al., 2018. First report of the fall armyworm, Spodoptera frugiperda (Lepidoptera: Noctuidae), natural enemies from Africa. J. Appl. Entomol., 142, 800-804, doi.org/10.1111/jen.12534

Sisay B. et al., 2019a. The efficacy of selected synthetic insecticides and botanicals against fall armyworm, Spodoptera frugiperda, in maize. Insects, 10(45), 1-14, doi.org/10.3390/insects10020045

Sisay B. et al., 2019b. Fall armyworm, Spodoptera frugiperda infestations in East Africa: assessment of damage and parasitism. Insects, 10(195), 1-10, doi. org/10.3390/insects10070195

Sun B. et al., 2020. First report of Ovomermis sinensis (Nematoda: Mermithidae) parasitizing fall armyworm Spodoptera frugiperda (Lepidoptera: Noctuidae) in China. J. Nematol., 52, 1-7, doi.org/10.21307/ jofnem-2020-050

Tendeng E. et al., 2019. The fall armyworm Spodoptera frugiperda (J. E. Smith), a new pest of maize in Africa: biology and first native natural enemies detected. Int . J. Biol. Chem. Sci., 13(2), 1011-1026, doi.org/10.4314/ ijbcs.v13i2.35

Thakore Y., 2006. The biopesticide market for global agricultural use. Ind. Biotechnol., 2(3), 194-208, doi. org/10.1089/ind.2006.2.194

Vega F.E., 2018. The use of fungal entomopathogens as endophytes in biological control: a review. Mycologia, 110(1), 4-30, doi.org/10.1080/00275514.2017.1418578

Wojcik B., Whitcomb W.H. \& Habeck D.H., 1976. Host range testing of Telenomus remus (Hymenoptera: Scelionidae). Florida Entomol., 59(2), 195-198, doi. org $/ 10.2307 / 3493972$

Yarou B.B. et al., 2017. Plantes pesticides et protection des cultures maraichères en Afrique de l'Ouest (synthèse bibliographique). Biotechnol. Agron. Soc. Environ., 21(4), 288-304.

Yigezu G. \& Wakgari M., 2020. Local and indigenous knowledge of farmers management practice against fall armyworm (Spodoptera frugiperda) (J. E. Smith) 
(Lepidoptera: Noctuidae): a review. J. Entomol. Zool. Stud., 8(1), 765-770.

Young J.R. \& McMillian W.W., 1979. Differential feeding by two strains of fall armyworm larvae on carbaryl treated surfaces. J. Econ. Entomol., 72, 202-203, doi. org/10.1093/jee/72.2.202

(91 ref.) 